\title{
SCREENING OF ANTIMICROBIAL POTENTIAL AND BIOACTIVE COMPONENTS OF SELECTED MEDICINAL PLANTS AGAINST INFECTIOUS BACTERIAL ISOLATES FROM LEUKEMIA PATIENTS
}

\author{
Afnan Lafai Alsulami, Munazza Gull* \\ Department of Biochemistry, Faculty of Science, King Abdulaziz University, Jeddah, Saudi Arabia \\ Received - June 15, 2018; Revision - August 21, 2018; Accepted - September 13, 2018 \\ Available Online - October 5, 2018
}

DOI: http://dx.doi.org/10.18006/2018.6(5).836.849

KEYWORDS
Antibacterial activity
Blood cancer
Nigella sativa
Phenolic compounds

\begin{abstract}
In the present study, an attempt was made to understand the occurrence of secondary infections in immuno-suppressed blood cancer patients and herbal suppression of these infections. The antibacterial potential of the ethanolic and methanolic crude extracts of ten medicinal plants against five clinical microbial isolates of blood cancer cases were evaluated through disc diffusion assay. Among the tested plants Nigella sativa extract showed highest antimicrobial potential followed by Lawsonia inermis, while Ficus carica exhibited least antimicrobial activity. The maximum zone of inhibition (16mm) was observed against Streptococcus viridans by the extract of Nigella sativa. Phenolics analysis by high performance liquid chromatography ultraviolet detector (HPLC-UV) revealed that parahydroxy benzoic acid was the major phenolic acid found in Olea europaea $(797.8 \mathrm{ng} / \mathrm{g}$ ) and Mentha longifolia (367.98ng/g) while highest concentration of gallic acid was reported from L. inermis $(3936.86 \mathrm{ng} / \mathrm{g}$ ) and vanillic acid (1942.51ng/g) in Ficus carica. These results indicated that phenolic compounds play an important role in pathogenic bacteria's cell growth inhibition and could be used as future antimicrobial and chemotherapeutic agent. Further, N. sativa, L. inermis, Boswellia sacra and Trigonella foenumgraecum plant extracts showed highest antimicrobial potential against microbial isolates isolated from blood cancer patients.
\end{abstract}

* Corresponding author

E-mail: munagull@hotmail.com (Dr. Munazza Gull)

Peer review under responsibility of Journal of Experimental Biology and Agricultural Sciences.

Production and Hosting by Horizon Publisher India [HPI] (http://www.horizonpublisherindia.in/).

All rights reserved.
All the article published by Journal of Experimental Biology and Agricultural Sciences is licensed under a Creative Commons Attribution-NonCommercial 4.0 International License Based on a work at www.jebas.org.

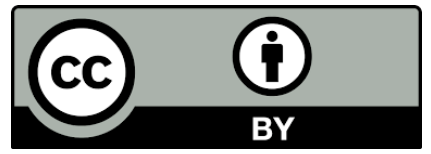




\section{Introduction}

Cancer is now the third leading cause of death worldwide, with $>12$ million new cases and 7.6 million cancer deaths estimated to have occurred (Garcia et al., 2007; Karpinski \& Adamczak, 2018). By 2030 , it is projected that there will be 26 million new cancer cases and 17 million cancer deaths per year (Boyle \& Levin, 2008; Hanahan \& Weinberg, 2011). Moreover, the global distribution of cancer and types of cancer that predominate continues to change, especially in economically developing countries. Low and middle income countries accounted about half (51\%) of all cancers worldwide in 1975; this proportion increased to $55 \%$ in 2007 and projected to reach $61 \%$ by 2050 (Worldwide Cancer Statistics, 2018). According to Bray \& Moller (2006) cancer particularly leukemia patients are highly susceptibility against bacterial and fungal infections. These infections might be an important cause of mortality and morbidity for febrile neutropenic cancer patients. In recent years, the introduction of novel chemotherapeutic bio factors and use of bio agents chemotherapeutic ways for leukaemia patients have improved the stand point of this disease, because a large number of patients are alleviating their clinical health by this biotherapy. But such intense chemotherapy with cytotoxic drugs usually results in myelosuppression and as a resultant high risk of neutropenia (absolute neutrophil count $<0.5 \times 109 / \mathrm{L}$ ) (Bow et al., 2006). It has a damaging effect on the normal human skin and mucosa, which leads to the risk of persistent bacterial, viral and fungal infections as phagocytic activity of the neutrophils impairs by neutropenia (Hotchkiss \& Karl, 2003). The patients diagnosed with malignancies and getting chemotherapy, found at higher risk of neutropenia and resultant all kind of infections and thus treated as immunocompromised cases (Groll \& Walsh, 2002).

The development of novel techniques in curative arena, particularly after the threat of drug resistance emergence, the use of conventional medicines and the plant-based herbal treatments have been focused and reconsidered as a great source of chemotherapeutic bioaids in all health systems of humans and animals throughout the world (Mahima et al., 2013).

The use of plants in medicine ranges from crude preparations or extracts, to refined extracts and individual bioactive compounds. Approximately $50 \%$ of 850 small molecules introduced as drugs over the last 20 years were derived from medicinal plants, plantderived or plant mimetics, meaning that the synthetic medicinal compounds were discovered from the study of plants (Fowler, 2006). An extensive program at the National Cancer Institute (NCI) screened around 114,000 extracts from an estimated 35000 plant samples for anticancer activity (Balunas \& Kinghorn, 2005).
Today, the use of plant drugs has been accepted all over the world. About $57 \%$ of the top-selling prescription in the USA contains natural products or derivatives, and one out of three Americans consumes herbal drugs (Newman \& Cragg, 2007). In developing countries, the use of medicinal plants has significantly increased due to the low income of the population. About $80 \%$ of the people are dependent, wholly or partially, on plant-based drugs (Kuete et al., 2010; Kumari et al., 2018).

Plant derived medicines are usually considered as relatively more safer than synthetic drugs, these have less side effects, intense therapeutic cure and more cost effectiveness (Sher \& Hussain, 2009; Iqbal et al., 2017). In wild plants, the lack of infective diseases is the great indication of their successful defense mechanisms against diseases. The defenses mechanisms of these plants are associated to the presence of a huge number of biochemical compounds like alkaloids, phenols, terpenes derivatives compounds and many other antimicrobial agents. Anti microbial compounds that make the essential oils from plants are more précised and evolved in their defensive mode of action against a wide range of pathogenic microorganisms. Thus, the essential oils from plants could have been used as alternative and improved supplements for the treatments of pathogenic infections (Akthar et al., 2014). Keeping in view the potential of medicinal plants as antimicrobial agent against clinical bacterial isolates of cancer patients, the objective of this study was to understand and characterize the bacterial clinical isolates/infections isolated from immuno-suppressed cancer patients through in vitro antimicrobial activity, compare the inhibitory effect of ten medicinal plants and to identify phenolics acids of the crude extracts of the plants using High-performance liquid chromatography ultraviolet detector (HPLC-UV).

\section{Materials and Methods}

The goal of in vitro antimicrobial activity testing is to provide a reliable predictor of an organism is likely to respond to sample test in the infected host.

\subsection{Selection of medicinal plants for this study}

Ten medicinal plants were collected from different regions of Saudi Arabia for this study, Nigella sativa (seeds), Ficus carica (leaves), Lepidium sativum (seeds), Lawsonia inermis (leaves), Azadirachta indica (leaves), Boswellia sacra (resins), Ocimum basilicum L. (leaves), Mentha longifolia L. (leaves), Trigonella foenum-graecum L. (seeds) and Olea europaea L. (leaves). The collected plants were identified in the laboratory by comparison of flora which made according to different references concerning with the medicinal plants (Royal Botanic Gardens Victoria, Indiana Native Plant \& Wildflower Society). 


\subsection{Preparation of plant crude extracts}

The seeds, leaves and resins plant parts were thoroughly washed to remove debris and the earth remains and allowed to dry under shade. The dried parts were grinded to fine powder. The plant extracts were prepared using the methanol and ethanol solvents. Air-dried plant extracts powder (25g) was taken in $100 \mathrm{ml}$ of $96 \%$ methanol and ethanol as a solvent for $24 \mathrm{hrs}$ in a water bath shaker $\left(37^{\circ} \mathrm{C}\right)$ and then the extract was filtered with whatman no. 1 filter paper and stored in air-tight amber bottles in refrigerator for further use as described by Jameela et al. (2011).

\subsection{Preparation of microbial inoculums}

Forty-five bacterial isolates were collected from patients with infection from the radiotherapy unit of King Abdulaziz Medical City, Jeddah, Saudi Arabia. All the bacterial isolates were identified using API (Analytical Profile Index) system with biomerieux vitek 2 .

Stock bacterial cultures of clinical isolates were maintained at $4^{\circ} \mathrm{C}$ on nutrient agar slants until the antimicrobial assay. For culturing isolates, nutrient agar slants were prepared using yeast extract $(2 \mathrm{~g})$, peptone $(5 \mathrm{~g}), \mathrm{NaCl}(5 \mathrm{~g})$, meat extract $(1 \mathrm{~g})$, agar $(15 \mathrm{~g})$ and distilled water (1L). The final $\mathrm{pH}$ of prepared medium was adjusted to 7.0. All studied bacterial isolates which have $10^{4} \mathrm{CFU}$ $\mathrm{mL}^{-1}$ used as final inoculum. Five clinical isolates of blood cancer cases (Salmonella group B, Corynebacterium, Staphylococcus aureus, Klebsiella Pneumoniae and Streptococcus Viridans) were selected on the basis of random occurrence in samples for further studies. Active cultures for selected bacterial isolates were prepared by transferring a sterile loopful swap of culture to $5 \mathrm{ml}$ of nutrient broth and incubated at $37^{\circ} \mathrm{C}$ for $72 \mathrm{hrs}$ on shaker with $170 \mathrm{rpm}$ in order to make a bacterial suspension as described by Jayaram et al. (2004).

\subsection{Preparation of crude plants extract}

Dried and pounded plants powder $(25 \mathrm{mg})$ were dissolved in $99.8 \%$ methanol or ethanol $(100 \mathrm{ml})$ using a conical flask and plugged it with sterile cotton ball. The samples were placed for 24 hrs on shaker at $37^{\circ} \mathrm{C}$ and for another $24 \mathrm{hrs}$ at room temperature as described by Doss \& Pugalenthi, (2012). The extracts were filtered using whatman no.1 filter paper. The plant extracts were evaporated to dryness using rotary vacuum evaporator at $60^{\circ} \mathrm{C}$ under reduced pressure. After complete vacuum evaporation, plant extracts were dissolved in $0.25 \%$ Dimethyl Sulphoxide (DMSO), and stored at $4^{\circ} \mathrm{C}$ for further use (Dineshbabu et al., 2015). The solvent DMSO (2.5\%) that would not inhibit growth of the microorganisms was used as the negative control for all the experiments (Zgoda \& Porter, 2001).

\subsection{Paper disc diffusion assay}

The initial screening of the extracts for antibacterial activity was conducted by the disc diffusion assay. The dried plant extracts (25mg) were dissolved in dimethyl sulfoxide (DMSO) with a concentration of $2.5 \mathrm{mg} / \mathrm{ml}$. Inoculums of testing bacterial isolates was spread on Muller Hinton Agar (MHA) medium by a sterile inoculation loop, the loop is streaked in at least three directions over the surface of the nutrient agar to obtain uniform growth according to the standard protocol described by the National Committee of Clinical Laboratory Standards (concentration 200 $\mathrm{mg} / \mathrm{ml}$ ). The plates were dried for 5 minutes approximately before use. Sterile paper discs $(6 \mathrm{~mm}$ in diameter) were impregnated with $30 \mu 1$ of each plant extract and placed on the surface of Mueller Hinton agar plates, that already inoculated with testing bacterial isolates. Each disc was pressed down to ensure complete contact with the agar surface and distributed evenly so that they are no closer than $24 \mathrm{~mm}$ from each other, center to center. The plates were subsequently incubated at $37^{\circ} \mathrm{C}$ for $24 \mathrm{hrs}$. After incubation each plate was examined and the growth inhibition zones were quantified by measuring the diameter of the zone of inhibition in $\mathrm{mm}$ starting from the disc to the end of the clear zone. Filter paper discs containing dimethyl sulfoxide (DMSO) $25 \%$ without any test compounds served as a control and no inhibition was observed. Each assay was analyzed and recorded in triplicate according to method described by Kumara et al. (2009).

\subsection{Standard antibiotic analysis}

Mueller-Hinton agar plates that have been already inoculated with tested pathogenic bacteria were used to analyze the antimicrobial potential of standard discs of Ciprofloxacin antibiotic ( $30 \mu \mathrm{g} / \mathrm{disc})$. This antibiotic then further used as standard control in disc diffusion assay with plant extracts. During incubation, the antibiotic diffused away from discs creating a concentration gradient which appeared as inhibition zone around these discs. Inhibition zone diameters $(\mathrm{mm})$ were observed after $18 \mathrm{hrs}$ of incubation at $37^{\circ} \mathrm{C}$.

\subsection{Analysis of total phenolics}

Total phenolics content was estimated by the Folin- Ciocalteu method (Pourmorad et al., 2006). In this, $0.5 \mathrm{ml}$ of plant extracts or gallic acid (standard phenolic compound) was mixed with Folin Ciocalteu reagent $(5 \mathrm{ml})$ and aqueous $\mathrm{Na}_{2} \mathrm{CO}_{3}(4 \mathrm{ml}, 1 \mathrm{M})$. The mixtures were allowed to stand for 15 minutes and the total phenols were determined by colorimetry at $765 \mathrm{~nm}$. Gallic acid was used as a standard for calibration curve. Total phenolics values were presented in unit of $\mathrm{mg}$ equal gallic acid in $1 \mathrm{~g}$ dry plant powder. 


\subsection{Analysis of total flavonoids}

Total flavonoids content was determined by aluminium chloride method (Pourmorad et al., 2006). Plant extracts $(0.5 \mathrm{ml})$ were separately mixed with $1.5 \mathrm{ml}$ of solvent, $0.1 \mathrm{ml}$ of $10 \%$ aluminium chloride, $0.1 \mathrm{ml}$ of $1 \mathrm{M}$ potassium acetate and $2.8 \mathrm{ml}$ of distilled water. The plant extracts were kept at room temperature for 30 minutes to stabilize the mixture. The absorbance of the reaction mixture was measured with a spectrophotometer at $415 \mathrm{~nm}$. Quercetin was used as a standard estimation for calibration curve. Total flavonoids values were recorded in the unit of $\mathrm{mg}$ equal quercetin in $1 \mathrm{~g}$ dry plant powder.

2.9 High Performance Liquid Chromatography (HPLC) analysis of phenolic compounds

High performance liquid chromatography analysis with UV detection was performed for the estimation of the phenolic compounds in the plant extracts. The shaded dried plant material (200g) was crushed to make it coarse powder. The coarse powder $(20 \mathrm{~g})$ was grinded with $25 \mathrm{ml}$ distilled water of $2 \mathrm{~N}-\mathrm{HCl}$. The grinded plant extracts were heated in water bath using air condenser at $100^{\circ} \mathrm{C}$ for $1 \mathrm{~h}$. The plant extracts were filtered using whatman filter paper No.1. By using a separating funnel, the filtrate was extracted with diethyl ether. The layer of diethyl ether was washed and separated with distilled water and dried over sodium sulphate (anhydrous). The final evaporated extract was obtained using rotary vacuum evaporator at $25^{\circ} \mathrm{C}$. The collected extract re-dissolved in HPLC grade ethanol $(5 \mathrm{ml})$, prior to the injection into HPLC column. The samples were filtered through $0.22 \mu \mathrm{m}$ organic filter (Millipore) before use (Joshi, 2011).

\subsubsection{Analyses of individual phenolic acids by HPLC}

The reverse phase high performance liquid chromatography (RPHPLC) analysis was performed for the estimation of phenolic acids compounds like gallic acid, parahydroxy benzoic acid, vanillic acid, syringic acid and ferulic acid. During study, used HPLC apparatus was HPLC-Beckman model-322 equipped with 100A model pump, 210 injector, 420 controller, mixer and BD-40 recorder. C18 column (ultrasphere) with specification of $5 \mu \mathrm{m}$ ( 25 $\mathrm{cm} \times 4.6 \mathrm{~mm}$ length). Mobile phase was setup strictly with this ratio, methanol: water (1\% acetic acid in 20: $80 \mathrm{v} / \mathrm{v})$. Prior to use in HPLC, mobile phase was degased. Flow rate was maintained at $1 \mathrm{ml} \mathrm{min}{ }^{-1}$ with chart speed $1 \mathrm{~cm} \mathrm{~min}^{-1}$. UV detector was fixed with $\max 280 \mathrm{~nm} \lambda$, aufs Attenuation (0.02) and isocratic mode. For individual phenolic compound, the detector response was calibrated and measured with standard phenolic acids strictly as described by Tandon et al. (2001). All standard phenolic compounds were procured from Sigma-Aldrich chemical company, USA.

\subsection{Statistical Analyses}

All measurements were performed in triplicate and the results were represented as mean \pm SEM. Multiple comparisons of means were performed by men whitney test. In all data analyses a value of $\mathrm{P}<0.05$ was considered as statistically significant. All computations were made by employing the statistical software (SPSS, version 11.0).

\section{Results}

\subsection{Evaluation of Antimicrobial Potential of selected Medicinal Plants parts}

The goal of antimicrobial activity test was to estimate the antimicrobial potential of selected medicinal plants against isolated bacteria. Antimicrobial activity was recorded in the diameter $(\mathrm{mm})$ of inhibitory zone formed around the disc (Table 1). Among methanol crude extracts $N$. sativa showed maximum inhibitor activity $(16 \mathrm{~mm})$ against Streptococcus viridans (Figure 1) while L. sativum showed minimum inhibitor activity $(2 \mathrm{~mm})$ while in case of ethanol extract $L$. inermis had highest antimicrobial activity $(9 \mathrm{~mm})$ against $\mathrm{S}$. viridans as compared to other plants, while $F$. carica had less activity $(0.25 \mathrm{~mm})$ against Staphylococcus aureus. The control DMSO discs showed no inhibitory zones. Among various tested microorganisms, Klebsiella pneumoniae has been shown highest resistant against the used plant extracts and antibiotics.

The good antimicrobial potential was also depicted by methanolic extract of $B$. sacra, T. foenum-graecum and $O$. basilicum as compared to ethanol extracts. The largest inhibition zones of $B$. sacra were observed for methanol extract against $S$. viridian with $12.4 \mathrm{~mm}$ and Salmonella Group B $9.75 \mathrm{~mm}$ zone size respectively. The methanol extract of $T$. foenum-graecum showed inhibition zone $(11.8 \mathrm{~mm})$ against Salmonella Group B while the zone of inhibition against Corynibacteria isolates was found $(11.5 \mathrm{~mm})$.

The highest effect of ethanol extract against $S$. viridian was observed with $6.4 \mathrm{~mm}$ zone of inhibition. Methanol extract of $O$. basilicum showed maximum inhibition zone $(3 \mathrm{~mm})$ against Corynibacteria. High antimicrobial activity for ethanol extract of $M$. longifolia and $O$. europaea were recorded as compared to methanol extracts of these plants. The ethanol extract of $M$. longifolia against Staphylococcus aureus showed $7 \mathrm{~mm}$ zone of inhibition and for Corynibacteria $(4 \mathrm{~mm})$ respectively. The methanol extract showed antimicrobial effect against $S$. viridian with $3.6 \mathrm{~mm}$ zone of inhibition. The inhibition zone against Corynibacteria for ethanol extract of Olea europaea was observed $(4 \mathrm{~mm})$ and Staphylococcus aureus $(9 \mathrm{~mm})$. While the methanol extracts depicted only $4 \mathrm{~mm}$ inhibition zone against Streptococcus viridian and $3 \mathrm{~mm}$ for Corynibacteria isolates. 


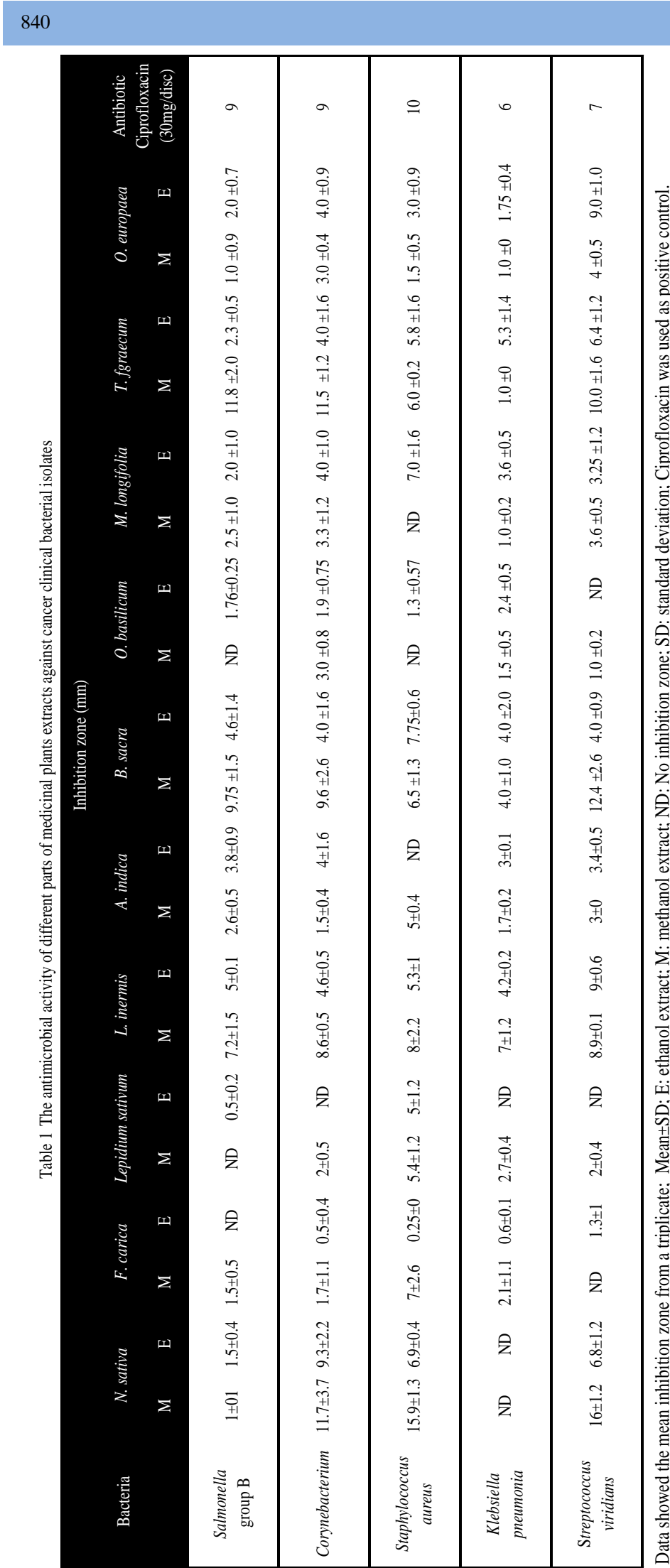




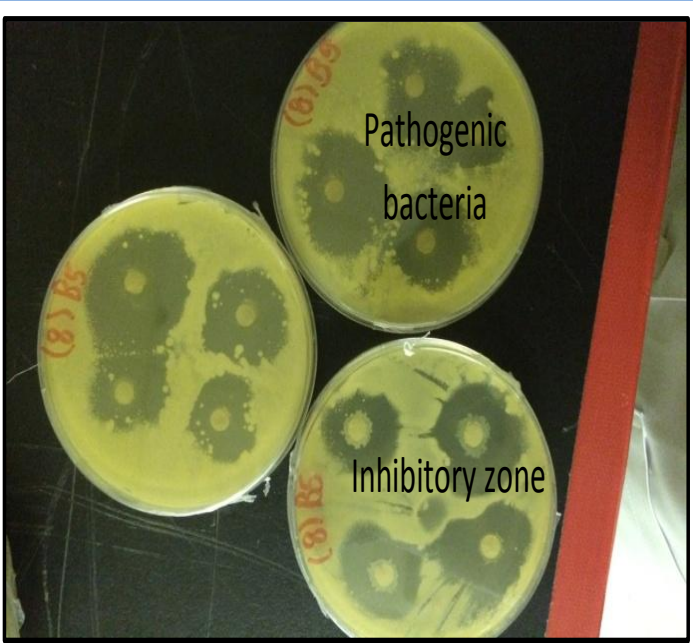

a. Ethanol extract against Corynebacterium

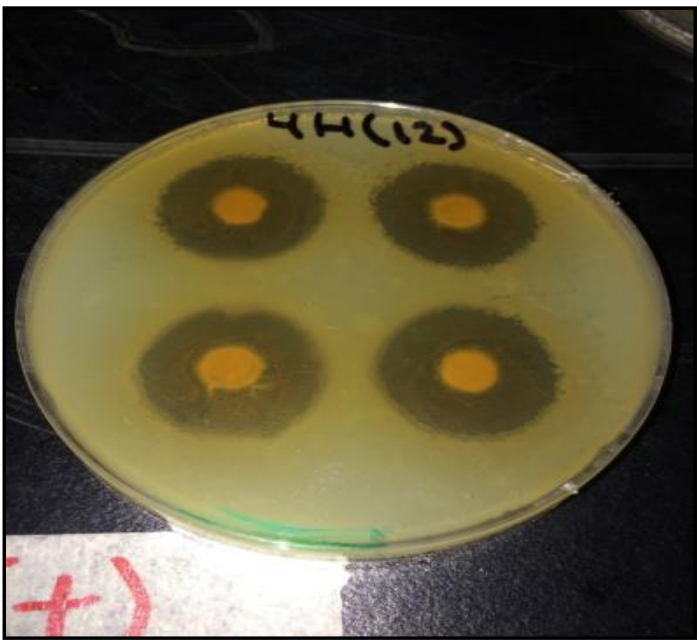

c. Ethanol extract against Streptococcus viridans

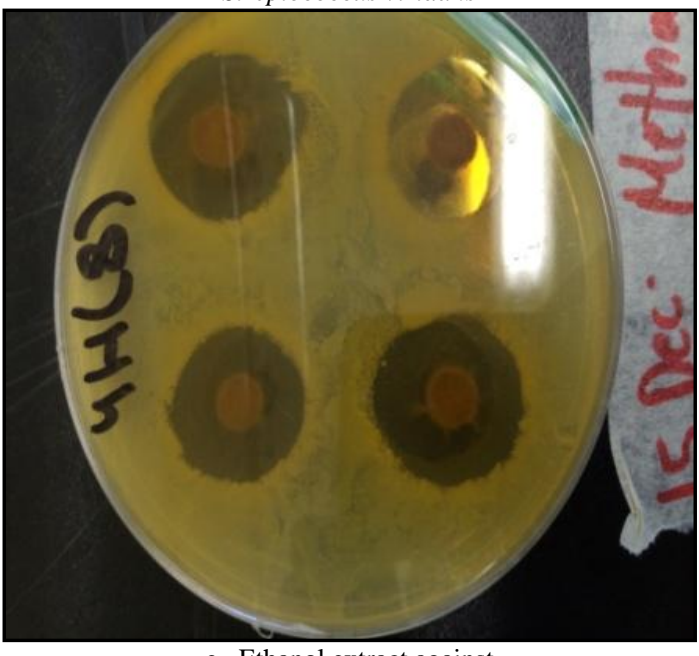

e. Ethanol extract against

Staphylococcus aureus

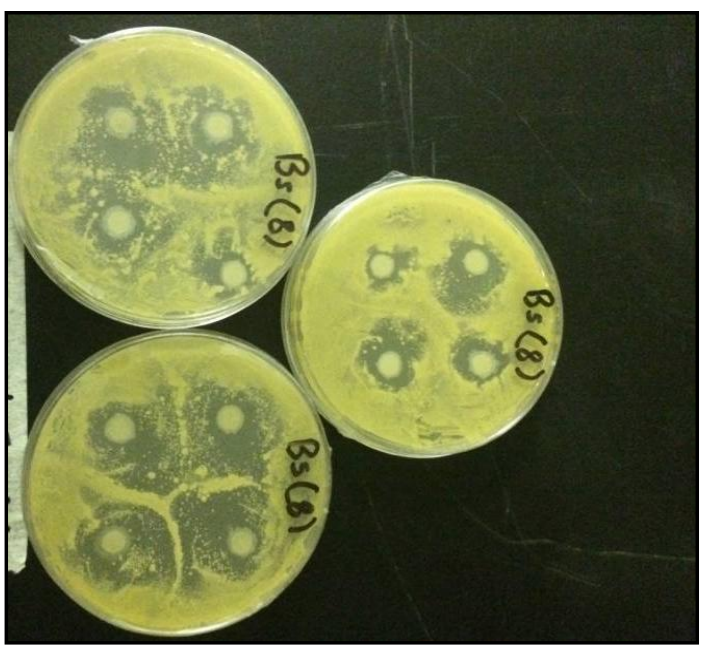

b. Methanol extract against Corynebacterium

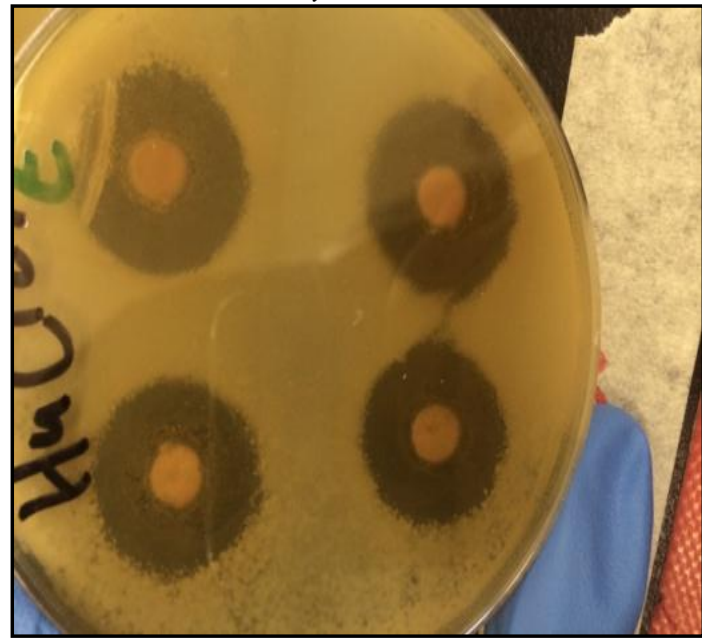

d. Methanol extract against

Streptococcus viridan

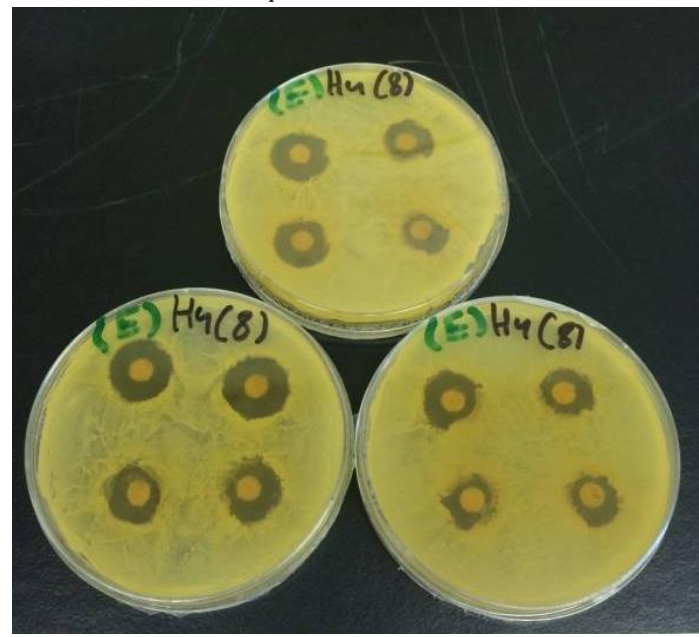

f. Methanol extract against

Staphylococcus aureus

Figure 1 Antimicrobial activity of Nigella sativa extracts (zone of inhibition).

Journal of Experimental Biology and Agricultural Sciences http://www.jebas.org 


\subsection{Analyses of total phenolics and total falvonoids}

Phenols and flavonoids are the most wide spread secondary metabolites in plant kingdom. These two groups have received much attention as potential natural antioxidant in terms of their ability to act as both efficient radical scavengers and metal chelator (Rice-Evans et al., 1995). The present study showed that the leaves and seed extracts of all selected plants contained significantly higher amount of phenolics and flavonoids compounds. Total phenolics content ranged from 8.651 \pm 0.321 to $5232 \pm 0.231 \mathrm{mg} \mathrm{GAE} / \mathrm{g}$ (gallic acid equivalent) while flavonoids content ranged between $4.023 \pm 0.70$ and $2282 \pm 0.45 \mathrm{mg}$ quercetin equivalent per $\mathrm{g}$ extracts (Table 2 ).

\subsection{Analyses of individual phenolic acids by HPLC}

The presence of phenolic compounds were identified by the comparison of their retention times and UV spectra to those of authentic standards analyzed under identical conditions. Qualitative and quantitative analysis of phenolic acids from ten medicinal plants depicted that gallic acid and ferulic acid were detected in all tested plants with different concentrations (Table 3).

Table 2 Total phenolic and flavonoid contents in ten tested medicinal plant extracts $(n=3)$

Plant crude extracts samples Plant parts investigated

Total phenolics (mg/g GAE) A Total flavonoids (mg/g QE) B

\begin{tabular}{|cccc|}
\hline Nigella sativa & seeds & $116.09 \pm 0.30$ & $194.04 \pm 11.65$ \\
\hline Ficus carica & leaves & $52.296 \pm 5.23$ & $14.38 \pm 0.33$ \\
\hline Lepidium sativum & seeds & $8.651 \pm 0.32$ & $4.023 \pm 0.081$ \\
\hline Azadirachta indica & leaves & $43.7 \pm 0.06$ & $529.5 \pm 0.14$ \\
\hline Lawsonia inermis & leaves & $5232.4 \pm 0.23$ & $107.33 \pm 0.12$ \\
\hline Boswellia sacra & resins & $315.97 \pm 10.04$ & $37.19 \pm 11.04$ \\
\hline Ocimum basilicum & leaves & $43.56 \pm 2.13$ & $4.21 \pm 0.70$ \\
\hline Mentha longifolia & leaves & $45.25 \pm 0.17$ & $25.17 \pm 11.2$ \\
\hline Trigonella foenum-graecum & seeds & $1813 \pm 0.32$ & $2,282 \pm 0.45$ \\
\hline Olea europaea & leaves & $103.99 \pm 0.04$ & $79.71 \pm 0.08$ \\
\hline
\end{tabular}

*All values are expressed as mean \pm SEM for three determinations indicates significance at $\mathrm{p}<0.05$;

A mg gallic acid equivalents (GAE)/g extract; B mg quercetin equivalents $(\mathrm{QE}) / \mathrm{g}$ extract

Table 3 HPLC analyses of individual phenolic acids in selected medicinal plants

\begin{tabular}{|c|c|c|c|c|c|}
\hline $\begin{array}{l}\text { Plant crude extracts } \\
\text { samples }\end{array}$ & $\begin{array}{l}\text { Gallic acid } \\
\text { (ng/g) }\end{array}$ & $\begin{array}{l}\text { Parahydroxy benzoic } \\
\text { acid (ng/g) }\end{array}$ & $\begin{array}{l}\text { Vanillic acid } \\
\text { (ng/g) }\end{array}$ & Syringic acid (ng/g) & $\begin{array}{l}\text { Ferulic acid } \\
\text { (ng/g) }\end{array}$ \\
\hline Nigella sativa & 12.58 & ND & ND & 5.66 & 5.58 \\
\hline Ficus carica & 1172.79 & 1814.18 & 1942.51 & 445.54 & 236.88 \\
\hline Lepidium sativum & 896.37 & 595.03 & ND & ND & ND \\
\hline Azadirachta indica & 1548.42 & 261.04 & ND & ND & 38.71 \\
\hline Lawsonia inermis & 3936.86 & 26.97 & 23.36 & 1201.88 & ND \\
\hline Boswellia sacra & 138.82 & ND & ND & ND & 10.14 \\
\hline Ocimum basilicum & 547.02 & 24.27 & ND & ND & 236.75 \\
\hline Mentha longifolia & 311.72 & 367.98 & 174.02 & 21.76 & 48.92 \\
\hline $\begin{array}{l}\text { Trigonella foenum- } \\
\text { graecum }\end{array}$ & 244.87 & 65.73 & ND & 21.52 & 129.57 \\
\hline Olea europaea & 397.91 & 797.8 & 140.42 & ND & 30.45 \\
\hline
\end{tabular}

$\mathrm{ND}=$ not detected; concentration of samples are in $\mathrm{ng} / \mathrm{g}=\mathrm{ppb}$;

Journal of Experimental Biology and Agricultural Sciences http://www.jebas.org 
The chromatogram (Figure 2) showed that one of the most abundant metabolites which have been reported from the methanolic extract of $N$. sativa seeds was gallic acid with retention time $\mathrm{tR}=3.46 \mathrm{~min}$ and para-hydroxybenzoic acid with retention time $\mathrm{tR}=10.43 \mathrm{~min}$.

HPLC analysis of the crude leaves extract of $F$. carica showed the presence of gallic acid with retention time $\mathrm{tR}=3.54 \mathrm{~min}$, protocatechuic acid with retention time $\mathrm{tR}=6.31 \mathrm{~min}$, vanillic acid with retention time $\mathrm{tR}=12.42 \mathrm{~min}$, syringic acid with retention time $\mathrm{tR}=13.31 \mathrm{~min}$, para-cumeric acid with retention time $\mathrm{tR}=$ $22.03 \mathrm{~min}$. The separation of the leaves crude extract of $L$. inermis compounds (Figure 3) occurred in the order listed (with the retention times given in parenthesis): gallic acid (3.51 min), para-

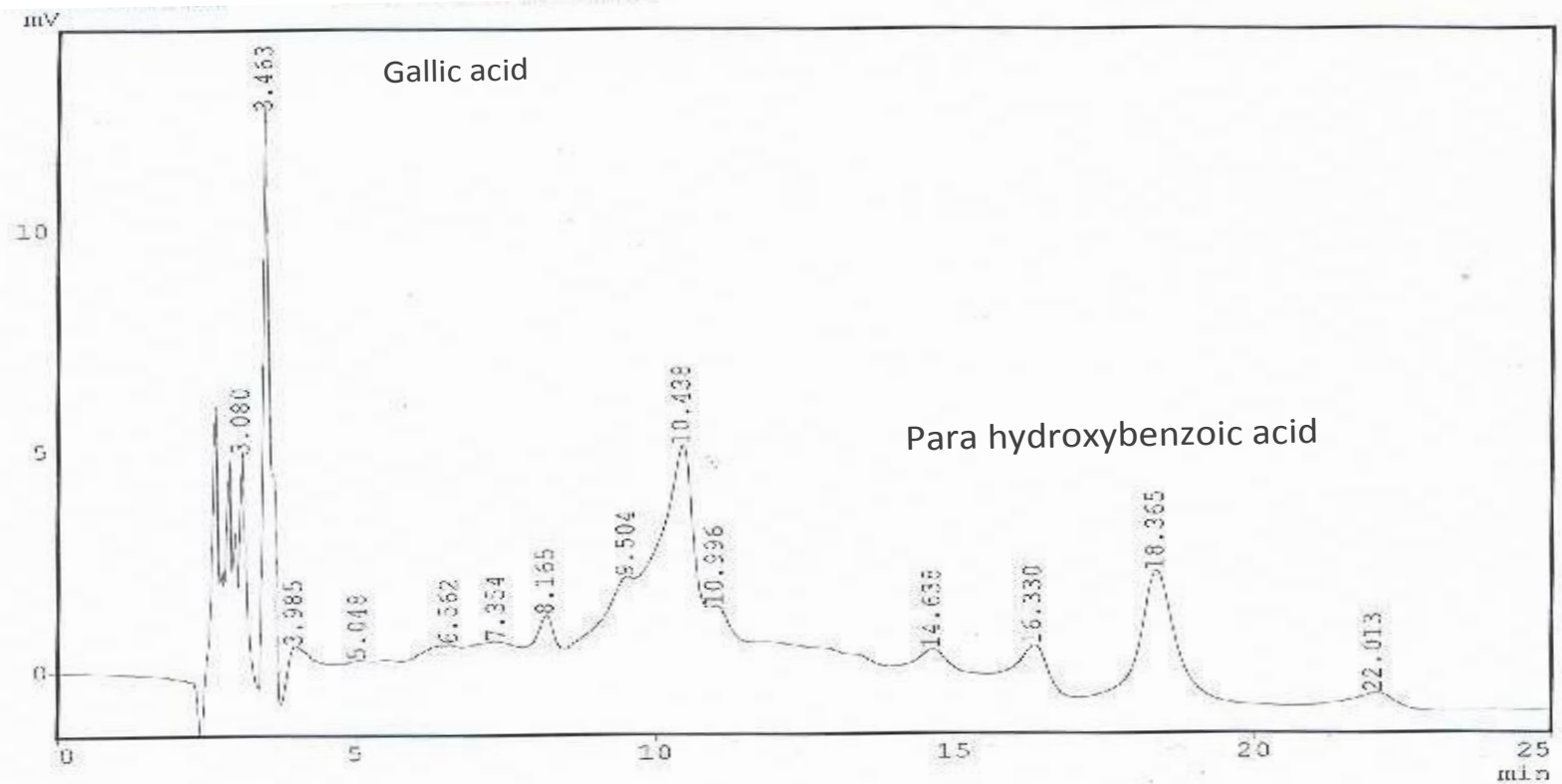

Figure 2 HPLC spectrum of the seeds crude extract of Nigella sativa/ black seed at $280 \mathrm{~nm}$ absorbance using methanol as solvent.

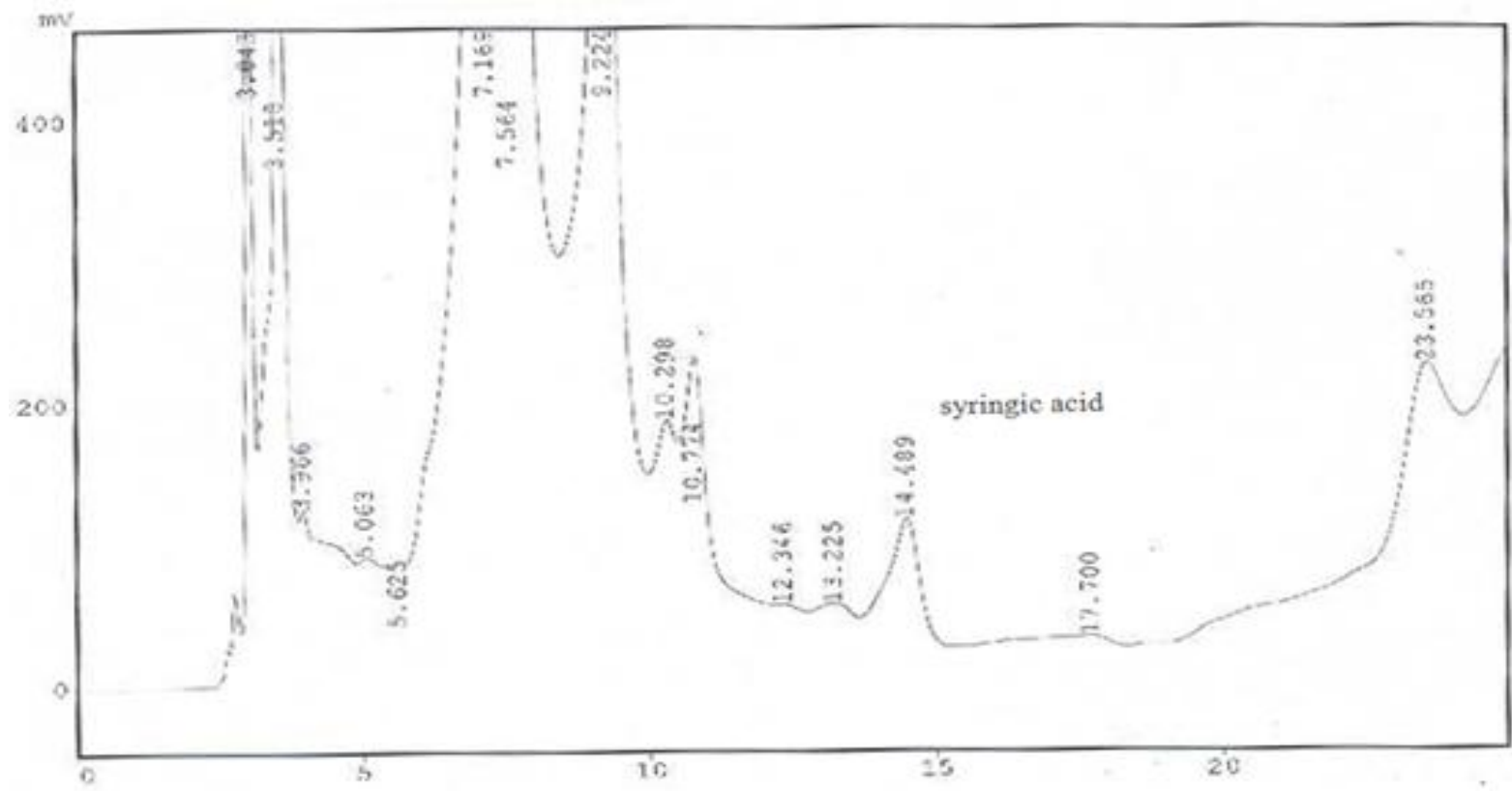

Figure 3 HPLC spectrum of the leaves crude extract of Lawsonia inermis at $280 \mathrm{~nm}$ absorbance using ethanol as solvent.

Journal of Experimental Biology and Agricultural Sciences http://www.jebas.org 
hydroxybenzoic acid (10.29 min), syringic acid (14.48 min), paracumeric acid (23.56 min). Highest concentration of Gallic acid was reported from the leaves extract of L. inermis (3936.86 ng/g) this was followed by $A$. indica leaf $(1548.42 \mathrm{ng} / \mathrm{g}), F$. carica leaf (1172.79 ng/g), L. sativum seed (896.37 ng/g) and N. sativa seed $(12.58 \mathrm{ng} / \mathrm{g})$. Para-hydroxybenzoic acid comes after gallic acid detected in all seed and leaf extracts. The highest amount of syringic acid $(1201.88 \mathrm{ng} / \mathrm{g})$ was reported from the leaf extract of L. inermis, this was followed by the Ficus carica leaf (445.54 $\mathrm{ng} / \mathrm{g}$ ) and $N$. sativa seed $(5.66 \mathrm{ng} / \mathrm{g})$. The highest concentration of parahydroxy benzoic acid $(797.8 \mathrm{ng} / \mathrm{g})$ was recorded in extract of $O$. europaea plant. In all tested ten plants, parahydroxy benzoic acid was observed except in B. sacra plant extract (Figure 4). While the highest concentration (174.02 ng/g) of vanillic acid and syringic acid $(21.76 \mathrm{ng} / \mathrm{g})$ were depicted in M. longifolia plant extracts respectively. In $T$. foenum-graecum, gallic acid was observed with the highest concentration $244.87 \mathrm{ng} / \mathrm{g}$ at retention time 3.549 minute and syringic acid was the lowest $21.52 \mathrm{ng} / \mathrm{g}$ at retention time 13.464 minute while vanillic acid was not detected (Figure 5).

\section{Discussion}

The antimicrobial effect of the medicinal plants is well documented and reported variously. Among all tested plants, $N$. sativa extracts have shown significant antimicrobial effect against the tested pathogens. Similar results were reported by Mashhadian \& Rakhshandeh (2005) when they tested the antibacterial and antifungal effects of $N$. sativa seeds extract against common and hospital strains of Candida albicans, Staphylococcus aureus and Pseudomonas aeruginosa and compared them with standard drugs such as clotrimazole, cloxacillin and gentamicin. Similarly, Niakan et al. (2006) studied antimicrobial potential of N. sativa seeds oil against two common Staphylococcus aureus strains and found significant inhibitory effect. This antimicrobial action could be attributed to the active ingredients especially thymoquinone and melanin (Zuridah et al., 2008). Since thymoquinone was found as the major component of this essential oil, it is claimed that it has great contribution in antimicrobial potential of the $N$. sativa seeds (Priya et al., 2004).

Further L. inermis, B. sacra and T. foenum-graecum plant extracts also showed great antimicrobial potential against pathogenic blood cancer isolates. The antimicrobial potential of three Boswellia species particularly against the Gram-positive bacteria was recorded very effective against Corynibacterium sp., Staphylococcus aureus, Salmonella typhi and Klebsiella pneumoniae pathogenic strains (Hasson et al., 2011). Essential oil of $M$. longifoli showed highest antimicrobial activity against Salmonella, Klebsiella pneumonia and Staphylococcus aureus strains supporting the observations of present study (Gulluce et al., 2007). Different solvents which included water, ethanol, methanol, ethyl acetate, n-hexane and diethyl ether were used for plant crude extraction of $O$. europaea and tested against pathogenic Klebsiella pneumonia, Salmonella and Staphylococcus aureus strains. The results were highly promising providing $O$. europaea as an effective medicinal plant (Hussain et al., 2014). In present study, all ten medicinal plants tested showed enormous

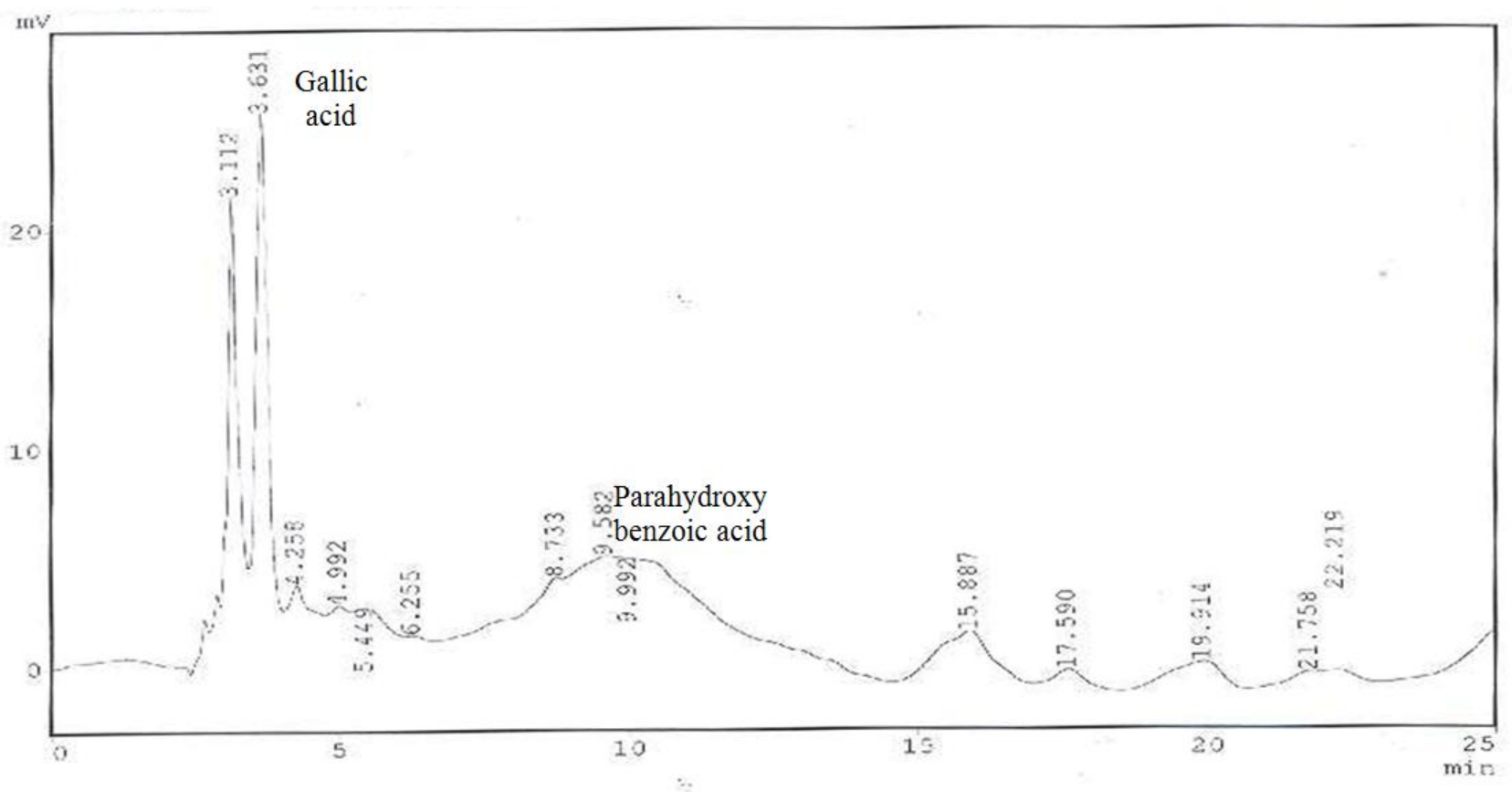

Figure 4 HPLC chromatogram of the studied Boswellia sacra recorded at $280 \mathrm{~nm}$

Journal of Experimental Biology and Agricultural Sciences http://www.jebas.org 


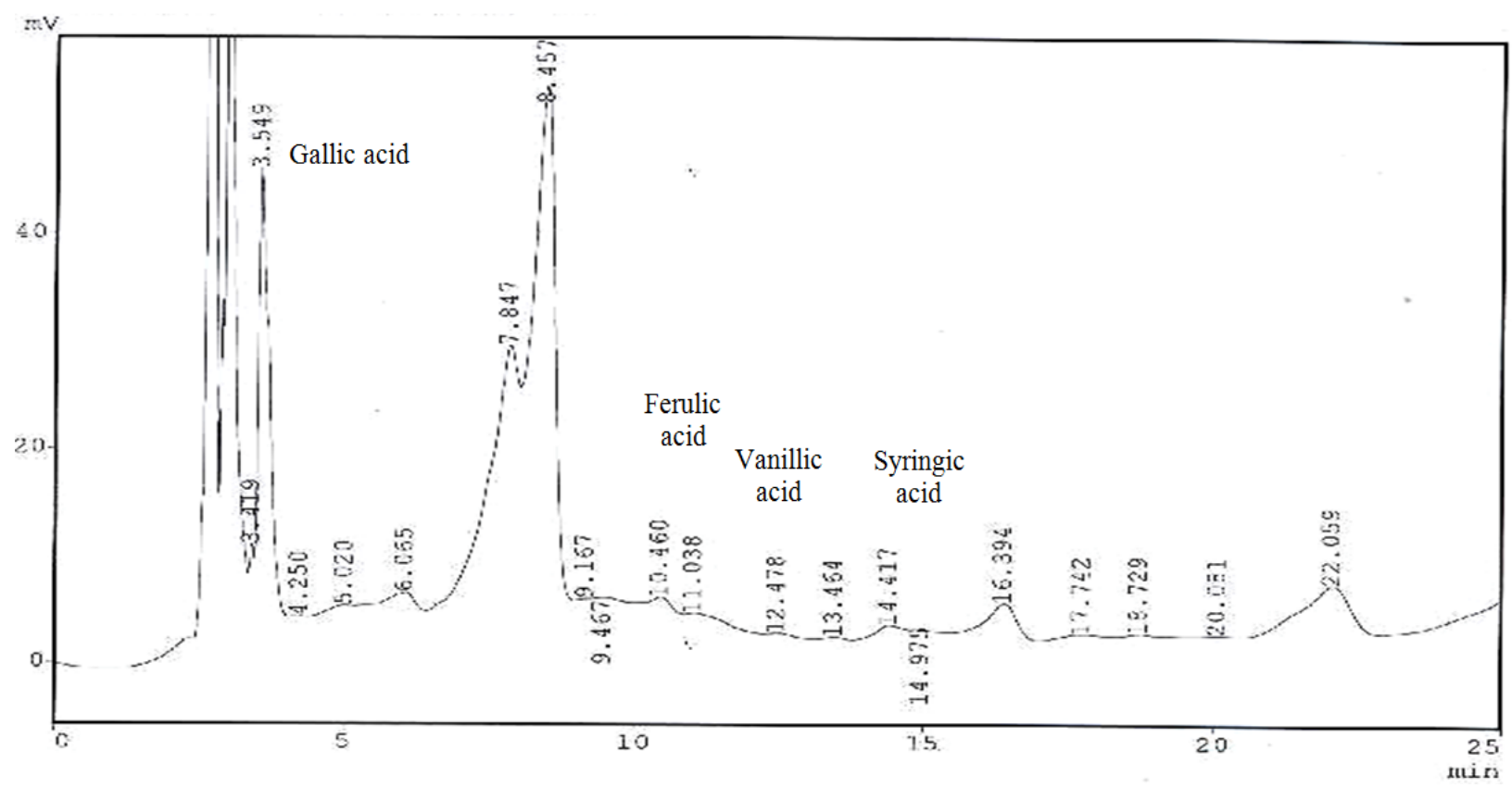

Figure 5: HPLC chromatogram of the studied Trigonella foenum-graecum seeds recorded at $280 \mathrm{~nm}$

antimicrobial potential against diverse group of bacteria. Different range of antimicrobial potential of these crude extracts could be due to variation in environmental and genetic factors. In plants, unusual chemotypes and the nutritional values of different parts (seeds, leaves, roots or stem) could also influence the crude extracts and oil compositions leads to antimicrobial activity differences (Ozcan \& Chalchat, 2002; Dubey et al., 2004; Kordali et al., 2005).

Medicinal plants have symbolized safety in contrast to the synthetic treatment (chemotherapy and radiotherapy).They play an essential role in the treatment of cancer. In cancer patients, the use of complementary and alternative medicine is the first desirable and recommended treatment with lesser side effects as compared to the synthetic chemical drugs (Ghavami et al., 2010).

This study also revealed a very interesting fact that all plant extracts were more effective on Gram positive than Gram negative bacteria. Gram negative bacteria have an effective natural permeability barrier in its outer membrane, which restricts the diffusion of amphipathic biochemical complexes (Tegos et al., 2002; Shan et al., 2007; Cueva et al., 2010).

The different biological activities depend on the plant secondary metabolites and regular consumption of these herbal products have serious consequences for health, it might be positive or negative (Mossini et al., 2009; Stobiecki \& Kachlicki, 2011). Polyphenols and falvonoids are used are used for cure and prevention of various diseases which are mainly associated with free radicals (Elansary et al., 2018). In present study, total phenolics content ranged from $8.651 \pm 0.321$ to $5232 \pm 0.231 \mathrm{mg}$ GAE/g (gallic acid equivalent) in the selected plant extracts. The total flavonoids content ranged between $4.023 \pm 0.70$ and $2282 \pm 0.45 \mathrm{mg}$ quercetin equivalent per g extracts. The entire plant kingdom contains phenolics and flavonoids which are important components of human and animal diet (Al-Jadidi \& Hossain, 2015; Bianchi et al., 2018). The biological properties of the plants have been attributed to the presence of active compounds like phenolic compounds (gallic acid, proto-catechuic acid, vanillic acid, syringic acid, para-cumeric acid, para-hydroxybenzoic acid). The leaves of L. inermis contain $3936.86 \mathrm{ng} / \mathrm{g}$ of gallic acid followed by $A$. indica leaf (1548.42 ng/g), Ficus carica leaf $(1172.79 \mathrm{ng} / \mathrm{g})$. Gallic acid is the most prominent phytoconstituents present in this plant leaves that could be responsible for its antimicrobial activity (Aliu, 2007).

Phenolic acids have significant biological and pharmacological characteristics and proved highly benefit for human health against pathogenic infection. These biochemical compounds are vital components of the human food having antioxidant and anticancer property and play an important role to reduce oxidative stress in human being (Harris et al., 2007). In various previous studies, gallic acid and ferulic acid were identified and quantified in ethanol crude extracts successfully (Juliani \& Simon, 2002; Laura et al., 2009). The phenolic compound gallic acid from plant crude extracts of Mentha longifolia and Mentha spicata found in 
common but differed in the content of other detected individual phenolic compounds (Vlase et al., 2014). Ferulic acid was also found in the ethanolic extract of Mentha longifolia aerial parts, but could not be quantified due to lesser amount of concentration (Al-Mandeel, 2013; Benedec et al., 2013). In leaves of olive plants, different phenolics like tyrosol, vanillin, hydroxytyrosol, caffeic acid,vanillic acid \& oleuropein were detected and reported variously. In olive fruit, vanillic acid, syringic acid, gallic acid and ferulic acid were also found (Kountouri et al., 2007; Sedef \& Karakaya, 2009; Viola \&Viola, 2009; Rababah et al., 2011). The phenolic acids were recorded quite susceptible to degradation when exposed to environmental stress like light, $\mathrm{pH}$, temperature, humidity and oxygen (Bianco et al., 2001) that explains the difference in antimicrobial potential of these plants also supporting the results of present study. The highest antimicrobial ptential of the methanol extracts observed in this study may be due to free hydroxyls that have the capability to combine and interact with the carbohydrates and proteins in the bacterial cell wall. They may be attached to enzyme sites rendering them inactive (Friedman \& Jurgens, 2000; Moreno et al., 2006; Stalikas, 2007). Therefore, the total analysis of chemicals amounts detected from the same plant and their corresponding antioxidant and antimicrobial activities may vary widely, depending on external conditions applied. It has been recognized that flavonoids show antioxidant activity and their effects on human nutrition and health are considerable. The mechanisms of action of flavonoids are through scavenging or chelating process that plays an active role in metabolism of living cells (Kessler et al., 2003).

\section{Conclusion}

Studies suggested that herbal medicines have a great potential in combating leukaemia. These medicinal plants parts could be the best candidate for future leukaemia therapy with minimal adverse effects, easier availability, and better acceptability as compared to chemotherapy and probably they will provide more potent antileukaemic agents in future. The present paper is a contribution to the studies on the pharmaceutical and antimicrobial potential of different medicinal plants from Saudi region. The results of this study demonstrated that different natural antimicrobials of plant origin could effectively inhibit various pathogenic blood cancer isolates, thus providing a good alternative to the use of current antimicrobials. The study revealed that the highest inhibitory effect of N. sativa crude extract was found against Streptococcus viridians. Also, Streptococcus viridian and Corynebacterium strains were found more sensitive as compared to Klebsiella pneumonia that showed highest resistance in antimicrobial activity. Promising antimicrobial potential of $N$. sativa, L. inermis, $B$. sacra and $T$. foenum-graecum plants were notably observed. More importantly, these medicinal plants seem to be a good source of several important phytochemicals, such as phenolics and falvonoids. Hence, further studies are needed to isolate pure compounds from the crude extract and to better understand the mechanism of such actions scientifically. These medicinal plant extracts also open the possibility of finding new clinically effective antibacterial compounds against multi-resistant pathogenic bacteria and pave the way toward the discovery of new antimicrobial drugs. Therefore, they could become a "preventive model" for infectious disease suppression and could be useful to improve the health of blood cancer cases.

\section{Conflict of interest}

Authors would hereby like to declare that there is no conflict of interests that could possibly arise.

\section{Funding sources}

This work was supported by King Abdulaziz City for Science and Technology (KACST) grant No. 54-37- TA.

\section{References}

Akthar MS, Degaga B, Azam T (2014) Antimicrobial activity of essential oils extracted from medicinal plants against the pathogenic microorganisms: a review. Biological Sciences and Pharmaceutical Research 2:001-007.

Aliu YO (2007) Pharmacodynamics: Veterinary Pharmacology ( $1^{\text {st }}$ ed.). Nigeria:Tamaza 29 publisher. Pp. 8-16.

Al-Jadidi HSK, Hossain MA (2015) Studies on total phenolics, total flavonoids and antimicrobial activity from the leaves crude extracts of neem traditionally used for thetreatment of cough and nausea. BENI-SUEF University Journal of Basic and Applied Sciences 4:93-98.

Al-Mandeel FA (2013) Investigation and chromatographic separation of some phenolic compounds from flowers of Mentha longifolia L. and Mentha spicata L. growing in Iraq. International Journal of Ayurvedic Medicine 4:352-360.

Balunas MJ, Kinghorn AD (2005) Drug discovery from medicinal plants. Life Sciences 78:431-441.

Benedec D, Vlase L, Oniga I, Mot AC, Silaghi-Dumitrescu R, Hanganu D, Tiperciuc B, Crişan G (2013) LC-MS analysis and antioxidant activity of phenolic compounds from two indigenous species of Mentha. Farmacia 61: 262-267.

Bianchi M, Canavesi R, Aprile S, Grosa G, Grosso ED (2018)Troxerutin, a mixture of $O$-hydroxyethyl derivatives of the natural flavonoid rutin: Chemical stability and analytical aspects. Journal of Pharmaceutical and Biomedical Analysis 150:248-257 
Bianco A, Buiarelli F, Cartoni G, Coccioli F, Muzzalupo I, Polidori A, Uccella N (2001) Anlaysis by HPLC-MS/MS of biophenolic components in olives and oils. Analytical Letters 34:1033-1051.

Bow EJ, Rotstein C, Noskin GA, Schwarer AP, Segal BH, Seymour JF, Szer J, Sanche S (2006) A randomized, open-label, multicenter comparative study of the efficacy and safety of piperacillin-tazobactam and cefepime for the empirical treatment of febrile neutropenic episodes in patients with hematologic malignancies. Clinical Infectious Diseases 43: 447-459.

Boyle P, Levin B (2008) World cancer report 2008. The International Agency for Research on Cance (IARC) Press, International Agency for Research on Cancer, Pp1-4.

Bray F, Moller B (2006) Predicting the future burden of cancer. Nature Reviews Cancer 6: 63-74.

Cueva C, Moreno-Arribas MV, Martín-Álvarez PJ, Bills G, Vicente MF, Basilio A, Basilio A, Rivas CL, Requena T, Rodriguez J, Bartolomé B (2010) Antimicrobial activity of phenolic acids against commensal, probiotic and pathogenic bacteria. Research in Microbiology 161:372-382.

Dineshbabu J, Srinivasan P, Manimekalai K, Guna GD, Darsini TP (2015) Uses of traditional medicinal plants against the biofilm forming Streptococcus pyogenes isolated from upper respiratory tract. International Journal of Pharma and Bioscience 6:464-479.

Doss A, Pugalenthi M (2012) Evaluation of antioxidant activity and phythochemical screening of Malus domestica borkh (apple) and Phaseolus vulgaris L. (green beans). Journal of Pharmaceutical and Scientific Innovation 1: 1-4.

Dubey NK, Kumar R, Tripathi P (2004) Global promotion of herbal medicines. India's opportunity. Current Science 86:37-41.

Elansary HO, Szopa A,Kubica PB, Ekiert H, Ali HM, Elshikh MS, Abdel-Salam EM, El-Esawi M,Diaa O. El-Ansary DO (2018) Bioactivities of traditional medicinal plants in Alexandria. Evidence-based complementary and alternative medicine Article ID 1463579:1- 13.

Fowler MW (2006) Plants, medicines and man. Journal of the Science of Food and Agriculture 86 :1797-1804.

Friedman M, Jürgens HS (2000) Effect of pH on the stability of plant phenolic compounds. Journal of Agricultural and Food Chemistry 48:2101-2110.

Garcia M, Jemal A, Ward EM, Center MM, Hao Y, Siegel RL, Thun MJ (2007) Global Cancer Facts \& Figures 2007. Atlanta, GA: American Cancer Society Pp. 1-3.
Ghavami G, Sardari S, Shokrgozar MA (2010) Anticancerous potentials of Achillea species against selected cell lines. Journal of Medicinal Plants Research 4:2411-2417.

Groll AH, Walsh TJ (2002) Invasive fungal infections in the neutropenic cancer patient: current approaches and future strategies. Infections in Medicine 19: 326-334.

Gulluce M, Sahin F, Sokmen M, Ozer H, Daferera D, Sokmen A, Ozkan H (2007) Antimicrobial and antioxidant properties of the essential oils and methanol extract from Mentha longifolia L. ssp. Longifolia. Food Chemistry 103:1449-1456.

Hanahan D, Weinberg RA (2011) Hallmarks of cancer: the next generation. Cell 144 : 646-74. doi: 10.1016/j.cell.2011.02.013.

Harris CS, Mo F, Migahed L, Chepelev L, Haddad PS, Wright JS, Willmore WG, Arnason JT, Bennett SA (2007) Plant phenolics regulate neoplastic cell growth and survival: a quantitative structure-activity and biochemical analysis. Canadian Journal of Physiology and Pharmacology 85:1124-1138.

Hasson SS, Al-Balushi MS, Sallam TA, Idris MA, Habbal O, AlJabri AA (2011) In vitro antibacterial activity of three medicinal plants-Boswellia (Luban) species. Asian Pacific Journal of Tropical Biomedicine 1:178-182.

Hotchkiss RS, Karl IE (2003) The pathophysiology and treatment of sepsis. New England Journal of Medicine 348: 138-150.

Hussain A, Qarshi IA, Liaqat R, Akhtar S, Aziz I, Ullah I, Shinwari ZK (2014) Antimicrobial potential of leaf and fruit extracts and oils of wild and cultivated edible olive. Pakistan Journal of Botany 46:1463-1468.

Iqbal J, Abbasi BA, MahmoodT, Kanwal S, Ali B, Shah SA, Khalil AT (2017) Plant-derived anticancer agents: A green anticancer approach. Asian Pacific Journal of Tropical Biomedicine 7:1129-1150.

Jameela M, Mohideen A, Sunitha K, Narayanan M (2011) Antibacterial activities of three medicinal plant extract against fish pathogens. International Journal of Biological Technology 2:57-60.

Jayaram H, Estes MK, Prasad BV (2004) Emerging themes in rotavirus cell entry, genome organization, transcription and replication. Virus Research 101:67-81.

Joshi RK (2011) Qualitative analysis of phenolic constituents from leaves of Anaphalis contorta. International Journal of Natural Products Research 1: 23-25.

Juliani HR, Simon JE (2002) Antioxidant activity of basil. Trends in New Crops and New Uses 5:575-579. 
Karpiński TM, Adamczak A (2018) Anticancer Activity of Bacterial Proteins and Peptides. Pharmaceutics 10: 54. DOI:10.3390/pharmaceutics10020054.

Kessler M, Ubeaud G, Jung L (2003) Anti and pro oxidant activity of rutin and quercetin derivatives. Journal of Pharmacy and Pharmacology 55:131-142.

Kordali S, Kotan R, Mavi A, Cakir A, Ala A, Yildirim A (2005) Determination of the chemical composition and antioxidant activity of the essential oil of Artemisia dracunculus and of the antifungal and antibacterial activities of turkish Artemisia absinthium, Artemisia dracunculus, Artemisia santonicum, and Artemisia spicigera essential oils. Journal of Agricultural and Food chemistry 53:9452-9458.

Kountouri AM, Mylona A, Kaliora AC, Andrikopoulos NK (2007) Bioavailability of the phenolic compounds of the fruits (drupes) of Olea europaea (olives): Impact on plasma antioxidant status in humans. Phytomedicine 14:659-667.

Kuete V, Dongfack MD, Mbaveng AT, Lallemand MC, VanDufat HT, Wansi JD, Seguin E, Tillequin F, Wandji J (2010) Antimicrobial activity of the methanolic extract and compounds from the stem bark of Drypetes tessmanniana. Chinese Journal of Integrative Medicine 16:337-343.

Kumara M, Agarwala R, Deyb K, Raib V, Johnsonc B (2009) Antimicrobial activity of aqueous extract of Terminalia chebula Retz on Gram positive and Gram negative microorganisms. International Journal of Current Pharmaceutical Research 1:56-60.

Kumari V, Kaushal K, Sharma AK, Mishra RC, Soni P (2018) Some phytochemicals found in medicinal plants used in cancer A Review. Medicinal Chemistry 8:18-20.

Laura A, Alvarez-Parrilla E, Gonzalez-Aguilar GA (2009) Fruit and vegetable phytochemicals: Chemistry, nutritional value and stability, John Wiley \& Sons, ISBN: 978-0-8138-0320-3,pp384.

Mahima, Ingle AM, Verma AK, Tiwari R, Karthik K, Chakraborty S, Deb R, Rajagunalan S, Rathore R, Dhama K (2013) Immunomodulators in day to day life: A review. Pakistan Journal of Biological Sciences 16: 826.

Mashhadian NV, Rakhshandeh H (2005) Antibacterial and antifungal effects of Nigella sativa extracts against $S$. aureus, $P$. aeroginosa and C. albicans. Pakistan Journal of Medical Sciences 21:47-52.

Moreno S, Scheyer T, Romano C, Vojnov A (2006) Antioxidant and antimicrobial activities of rosemary extracts linked to their polyphenol composition. Free Radical Research 40:223-231.
Mossini SAG, Arroteia CC, Kemmelmeier C (2009) Effect of neem leaf extract and neem oil on Penicillium growth, sporulation, morphology and ochratoxin A production. Toxins Journal 1:3-13.

Newman DJ, Cragg GM (2007) Natural Products as Sources of New Drugs over the Last 25 Years. Journal of Natural Products 70 :461-477.

Niakan M, Miri SRA, Naseri M, Karimi M, Mansouri S (2006) In vitro anti-Staphylococcus aureus activity of Nigella sativa L. seed oil extract, compared with CXM, CEC, MAN and CAZ antibiotics. Journal of Medicinal Plants 5:29-33

Ozcan M, Chalchat JC (2002) Essential oil composition of Ocimum basilicum L. and Ocimum minimum L. in Turkey. Czech Journal of Food Sciences 20: 223-228.

Pourmorad F, Hosseinimehr SJ, Shahabimajd N (2006) Antioxidant activity, phenol and flavonoid contents of some selected Iranian medicinal plants. African Journal of Biotechnology 5:1142-1145.

Priya KS, Arumugam G, Rathinam B, Wells A, Babu M (2004) Celosia argentea Linn. leaf extract improves wound healing in a rat burn wound model. Wound repair and regeneration 12:618625.

Rababah TM, Ereifej KI, Esoh RB, Al-u'datt MH, Alrababah MA,Yang W (2011) Antioxidant activities, total phenolics and HPLC analyses of the phenolic compounds of extracts from common Mediterranean plants. Natural Product Research 25:596605 .

Rice-Evans CA, Miller NJ, Bollwell PG, Bramley PM, Pridham JB (1995) The relative antioxidant activities of plant-derived polyphenolic flavonoids. Free Radical Research 22:375-383.

Sedef N El, Karakaya S (2009) Olive tree (Olea europaea) leaves: potential beneficial effects on human health. Nutrition Reviews 67: 632-638.

Shan B, Cai YZ, Brooks JD, Corke H (2007) The in vitro antibacterial activity of dietary spice and medicinal herb extracts. International Journal of Food Microbiology 117:112-119.

Sher H, Hussain F (2009) Ethnobotanical evaluation of some plant resources in northern part of Pakistan, African Journal of Biotechnology 8:4066-4076.

Stalikas CD (2007) Extraction, separation, and detection methods for phenolic acids and flavonoids. Journal of Separation Science 30:3268-3295. 
Stobiecki M, Kachlicki P (2011) Isolation and identification of flavonoids.In: Grotewold E (Ed.), The science of flavonoids. New York: Springer Science and Business Media, Pp. 47-69, 23-56.

Tandon S, Sand NK, Pant AK, Ram B (2001) Evaluation of phenolic acids from some plants of family Asteraceae. Pestology 25:30-31.

Tegos G, Stermitz FR, Lomovskaya O, Lewis K (2002) Multidrug pump inhibitors uncover remarkable activity of plant antimicrobials. Antimicrobial agents and chemotherapy 46:3133-3141.

Viola P, Viola M (2009) Virgin olive oil as a fundamental nutritional component and skin protector. Clinics in Dermatology 27:159-165.

Vlase L, Benedec D, Hanganu D, Damian G, Csillag I, Sevastre
B, Tilea I (2014) Evaluation of antioxidant and antimicrobial activities and phenolic profile for Hyssopus officinalis, Ocimum basilicum and Teucrium chamaedrys. Molecules 19:5490-5507.

Worldwide Cancer Statistics (2018) Available online: http://www.cancerresearchuk.org/health-professional/cancerstatistics/worldwide-cancer accessed on 16 January 2018.

Zgoda JR, Porter JR (2001) A Convenient microdilution method for screening natural products against bacteria and fungi. Pharmaceutical Biology 39:221-225.

Zuridah H, Fairuz ARM, Zakri AHZ, Rahim MNA (2008) In vitro antibacterial activity of Nigella sativa against staphylococcus aureus, Pseudomonas aeruginosa, Klebsiella pneumoniae, Escherichia coli and Bacillus cereus. Asian Journal of Plant Sciences 7:331-333.

Journal of Experimental Biology and Agricultural Sciences http://www.jebas.org 